\title{
Organ Donor
}

National Cancer Institute

\section{Source}

National Cancer Institute. Organ Donor. NCI Thesaurus. Code C100810.

Someone from whom an organ is removed for transplantation or other purpose. 